\title{
A comparison of clinical, hepatic and immunological effects of three different parenteral lipid emulsions in children
}

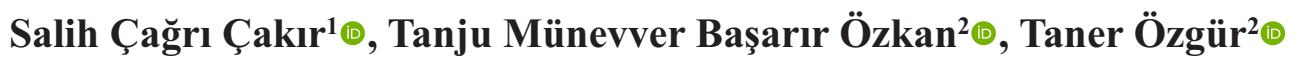 \\ ${ }^{1}$ Department of Pediatrics, Division of Neonatology, Bursa Uludağ University School of Medicine, Bursa, Turkey \\ ${ }^{2}$ Department of Pediatric Gastroenterology, Bursa Uludağ University School of Medicine, Bursa, Turkey
}

\begin{abstract}
Objectives: Lipid emulsions are not only considered as a source of energy, but also as a regulatory substance for key metabolic functions in different diseases. The aim of the present study was to compare clinical, biochemical and immunological effects of olive oil, soybean oil and omega-3 fatty acid which are administrated to the children in parenteral nutrition products.

Methods: Patients who were admitted to pediatric intensive care unit and had parenteral nutrition for 7 days are included in the study. The patients were randomised into 3 groups based on the admission order, including 10 patients in each group. The children in Group $\mathrm{O}$ were fed by a lipid emulsion based on olive oil; the children in Group S were fed by a soybean based lipid emulsion and the children in group F were fed by soybean based lipid emulsion with omega-3 based solution. Analysis were made on the first and the seventh day. Laboratory parameters as well as hemogram, biochemical analysis, immunoglobulins, lymphocyte subgroup panel and cytokine levels were evaluated just before parenteral nutrition (day 0 , basal value) and at day 7 of parenteral nutrition. Clinical monitoring parameters included body weight, and circumference of the mid-upper arm.

Results: Thirty children were enrolled into the study. Total cholesterol and triglyceride levels significantly increased in Group O whereas triglyceride level significantly increased in Group S. Hemogram, liver function tests, cytokine levels, lymphocyte sub-group distribution, immunoglobulin levels and total antioxidant capacity measurements were not different.

Conclusions: Three lipid emulsions which are used for parenteral nutrition treatment in intensive care unit patients are clinically and biochemically useful.

Keywords: intravenous lipid emulsions, parenteral nutrition, olive oil, fish oil, total antioxidant capacity, soybean oil
\end{abstract}

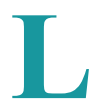
ipid emulsions are safely used in parenteral nutrition (PN) products for pediatric intensive care unit (PICU) patients who do not have sufficient enteral nutrition [1]. Lipid emulsions are one of the main components of parenteral nutrition to give sufficient energy, essential fatty acids and fat soluble vitamins
[1]. The issue that use of which lipid emulsion obtained from which herbal source for PN is still conflicting. Since the soybean oil (SO) based intravenous lipid emulsions (ILE) have excess linoleic acid (n-6 polyunsaturated fatty acid; PUFA), they thought to be responsible for increase in proinflammatory cytokines 
levels, decrease in immunological response, increase in free radicals and lipid peroxidation [2]. It was reported that olive oil (OO) based lipid emulsions would be more advantageous due to antioxidant protection with natural vitamin $\mathrm{E}$ and lower PUFA ingredient and the effect on immunological and inflammatory processes would be neutral due to dominant monounsaturated fatty acid (MUFA) content [2]. Use of fish oil (FO) was reported to provide antiinflammatory effects of docosahexaenoic acid (DHA) and eicosapentaenoic acid (EPA), omega-3 fatty acids [1]. As a result of these, lipid emulsions are not only considered as a source of energy, but also has a roleas a regulatory substance for key metabolic functions in different chronic and acute diseases. Possible effects of the lipids on such inflammatory processes are very important for the patients with sepsis whose excessive production of pro-inflammatory mediators contribute to mortality [3]. Furthermore, the risk of hypertriglyceridemia increases in intensive care unit patients under metabolic stress and this persists during intravenous lipid administration [4].

The aim of this study was to review and compare the effects of lipid emulsions based on soybean, olive oil and soybean with omega-3 fatty acid on hepatic, immunological and clinical processes.

\section{METHODS}

\section{Study Design}

This interventional study was admitted to the ethical board of Uludağ University School of Medicine. The ethics committee approval date and number is 2005-3. After approval of the ethics committee, 30 patients who were admitted to PICU within a year and had PN for 7 days were included in the study. Verbal and written consent was obtained from the patients. The patients were randomised into 3 groups based on the admission order, including 10 patients in each group. The children with type 1 diabetes, acid-base imbalance, metabolic disease, kidney failure and those who use anticoagulant, immunosuppressive agent, steroids and carnitin were excluded. The children in Group O were fed by a ILE based on OO (20\%, ClinOleic; Baxter, Maurepas, France); the children in Group S were fed by a SO based ILE (20\%, Ivelip; Clintec, Amilly, France) and the children in Group F were fed by SO based ILE (Ivelip) with omega-3 based 10\% FO solution (Omegaven; Fresenius Kabi, Bad Hamburg, Germany). Characteristics and content of the lipid emulsions used for the patients are shown in Table 1.

Fluid, electrolytes, trace elements, protein and calorie support were provided with PN to all patients. Lipid emulsions were administrated in a dose of 1 to $3 \mathrm{~g} / \mathrm{kg} /$ day to provide the protein-free energy between $20 \%$ to $50 \%$ in the nutrition fluids. Omega-3 fatty acid solution was administrated as $1 \mathrm{ml} / \mathrm{kg} /$ day.

\section{Laboratory Tests}

Laboratory parameters as well as hemogram, biochemical analysis, immunoglobulins, lymphocyte subgroup panel and cytokine levels were evaluated just before PN (day 0, basal value) and at day 7 of PN. Clinical monitoring parameters included body weight, and circumference of the mid-upper arm. Measurements were done by the same person with the same device. Biochemical analysis included blood glucose, total and direct biluribin, total protein, albumin, prealbumin, aspartate transaminase (AST), alanine transaminase (ALT), alkaline phosphatase (ALP), gamma glutamyl transferase (GGT), total cholesterol, low-density lipoprotein cholesterol (LDL), triglyceride (TG), high-density lipoprotein cholesterol (HDL), serum biliary acid level and they were detected through an Abbott Aeroset fully-automated biochemistry device. Total antioxidant capacity (TAC) levels were measured by calorimetric method (Aeroset, Abbott Diagnostics, IL, USA).

Hemogram, prothrombin time (PT), activated partial thromboplastin time (APTT) and international normalized ratio (INR) were analyzed. Immunoglobulins and C-reactive protein (CRP) were analyzed in Dade Behring BN II device through nephelometric method. Lymphocyte subgroups were detected in Beckman Coulter device through flow-cytometry method. Cytokines were analyzed through ELISA (Enzyme Linked Immuno Sorbent Assay) method. BioSource International Elisa kit was used for cytokine analysis. The values obtained in a Tecan brand optic density device at $450 \mathrm{~nm}$ wavelength were reevaluated on a graphic drawn according to optic density levels of standard solutions and cytokine levels $(\mathrm{pg} / \mathrm{ml})$ were found. 


\section{Statistical Analysis}

The statistical analysis were run through SPSS-23 (Statistical Package for Social Science) computer software.Kruskal Wallis test was used to compare variables in more than two groups without normal distribution, and the groups with significant differences in median values were exposed to binary comparison through Mann Whitney U test. Chi-Square test was used to evaluate differences between categorical variables. Median values of the parameters measured before and after PN were compared with Wilcoxon test. Percentage change of the patients in all groups at days 0 and 7 was calculated by the formula [(value at day 7 - value at day 0) / value at day 0]. The comparisons with a $p$ value $<0.05$ were accepted as statistically significant. Bonferroni's correction was done for $p$ value in multiple comparisons.

\section{RESULTS}

There was no statistically significant difference

Table 1. Composition of fat emulsions used in the study [19, 21, 24]

\begin{tabular}{|c|c|c|c|}
\hline \multirow[t]{2}{*}{ Contents of products } & \multirow[b]{2}{*}{ Fish oil-based } & \multicolumn{2}{|c|}{ Intravenous fat emulsion products } \\
\hline & & Soyabean oil-based & Olive oil-based \\
\hline \multicolumn{4}{|l|}{ Composition (g/100 mL) } \\
\hline Soyabean oil & - & 20 & 4 \\
\hline Olive oil & - & - & 16 \\
\hline EYPL & 1.2 & 1.2 & 1.2 \\
\hline Glycerol & 2.5 & 2.5 & 2.25 \\
\hline Sodium oleate & - & 0.03 & 0.03 \\
\hline Fish oil & 10 & - & - \\
\hline \multicolumn{4}{|l|}{ Fatty acids content (mol \%) } \\
\hline Palmitic acid & $2.5-10$ & 11 & 14.5 \\
\hline Stearic acid & $0.5-2$ & 4 & 3 \\
\hline Oleic acid & $6-13$ & 20 & 60 \\
\hline Linoleic acid & 4.4 & 52 & 18.5 \\
\hline$\alpha$-Linolenic acid & 1.2 & 8.5 & 2 \\
\hline Arachidonic acid & $1-4$ & 0.1 & 0.5 \\
\hline EPA & $12.5-28.2$ & - & - \\
\hline DHA & $14.4-30.9$ & 0.34 & 0.23 \\
\hline PUFA & 57.5 & 60.5 & 20.5 \\
\hline MUFA & 23 & 22.3 & 65 \\
\hline$\omega-6$ PUFA & 3.4 & 56 & 18 \\
\hline$\omega-3$ PUFA & 54 & 5.6 & 2 \\
\hline$\omega-6$ FA / $\omega-3$ FA ratio & $1: 8$ & $7: 1$ & $9: 1$ \\
\hline \multicolumn{4}{|l|}{ Vitamin $\mathbf{E}$} \\
\hline$\alpha$-tocopherol $\mu \mathrm{g} / \mathrm{mL}$ & 230 & 12.8 & 32 \\
\hline 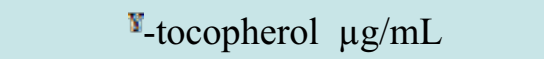 & 0.15 & 77 & 13.9 \\
\hline$\delta$-tocopherol $\mu \mathrm{g} / \mathrm{mL}$ & 0.01 & 51 & 10.5 \\
\hline$\alpha$-tocopherol/ PUFA mg/g & 2 & 0.2 & 0.75 \\
\hline
\end{tabular}

EYPL $=$ egg yolk phospholipids, EPA $=$ eicosapentaenoic acid, DHA $=$ docosahexaenoic acid, PUFA = polyunsaturated fatty acid, MUFA = monounsaturated fatty acid 
detected in age, gender, weight and diagnosis distributions of 30 patients enrolled into the study (Table 2).

When measurements of all groups at day 0 were compared, no statistically significant difference was detected except APTT. Initial APTT levels of all groups were within normal limits. The APTT value in Group $\mathrm{S}$ at day 0 was found significantly lower than Group F $[$ median $=22.5 \mathrm{sn}(\min =18, \max =51)$ vs median $=38(\min =22, \max =60), p=0.023$, respectively].

Within groups $\mathrm{O}, \mathrm{S}$ and $\mathrm{F}$, levels of the parameters measured before and after PN were compared statistically. Body weight was detected statistically and significantly higher in day 7 when compared with day 0 ( $p=0.026, p=0.018, p=0.012$, respectively).

Within the groups $\mathrm{O}, \mathrm{S}$, and $\mathrm{F}$, prealbumin levels at day 7 were found to be significantly higher in comparison to the levels of day 0 ( $p=0.005, p=0.008, p$ $=0.005$, respectively). Levels of ALP, TG and total cholesterol was detected significantly higher in Group $\mathrm{O}$ at day 7 when compared with the initial level ( $p=$ $0.005, p=0.037, p=0.025$, respectively). In Group $\mathrm{S}$, a statistically significant increase was detected in TG and APTT levels at day 7 when compared with the levels at day 0 ( $p=0.005, p=0.018$, respectively). There was no significant difference in glucose, AST, ALT, serum biliary acids, PT, INR, HDL, LDL, total bilirubin, direct bilirubin, total protein, albumin, TAC between days 0 and 7. The results were shown in Table 3.

There was no significant difference in CRP levels between the groups at days 0 and 7 ( $p=0.477, p=$
0.176 , respectively). None of the patients had positive blood culture during PN period. The CRP levels of day 7 were detected significantly lower than day 0 in all groups ( $p=0.046$ in Group $\mathrm{O}, p=0.036$ in Group $\mathrm{S}$, $p=0.033$ in Group F) (Table 3).

There was no significant difference in hemogram levels, immunoglobulin levels (IgG, IgM, IgA), lymphocyte subgroup distribution (CD4, CD8, CD19), cytokine levels (IL-1 beta, IL-12, IL-2, TNF-alpha) between day 0 and day 7 . Hemogram, immunological values and statistical evaluation are presented in Table 4.

Day 7 measurements showed significant increase in APTT levels ( $p=0.013, p=0.006$, respectively) and decrease in total bilirubin levels $(p=0.029, p=$ 0.01 , respectively) in Group S compared to Group O and Group F. There was no significantly changes between the groups in clinical presentation and laboratory analysis between day 0 and day 7 .

\section{DISCUSSION}

PN contributes positively to the growth and causes some positive or negative changes in biochemical, immunological, hematological and inflammatory parameters depending on lipid solutions. The present study reviewed effects of 3 different lipid solutions on clinical findings and laboratory tests prospectively.

In the literature review, it is reported that body weight monitoring in critically ill children is important to evaluate nutritional status [5]. Furthermore, similar to $\mathrm{SO}$ and $\mathrm{OO}$ based ILEs, short term PN procedure

Table 2. Demographic features of patients

\begin{tabular}{lcccc}
\hline $\begin{array}{l}\text { Gender, age and } \\
\text { diagnosis }\end{array}$ & $\begin{array}{c}\text { Group O } \\
(\mathbf{n}=\mathbf{1 0})\end{array}$ & $\begin{array}{c}\text { Group S } \\
(\mathbf{n}=\mathbf{1 0})\end{array}$ & $\begin{array}{c}\text { Group F } \\
(\mathbf{n}=\mathbf{1 0})\end{array}$ & $\boldsymbol{p}$ value \\
\hline Male/female, $\mathrm{n}$ & $6 / 4$ & $6 / 4$ & $5 / 5$ & 0.87 \\
\hline $\begin{array}{l}\text { Age (months), median } \\
\text { (minimum-maximum) }\end{array}$ & $6(2.5-132)$ & $38.5(2-144)$ & $8.5(2.5-96)$ & 0.492 \\
$\begin{array}{l}\text { Weight (kg), median } \\
\text { (minimum-maximum) }\end{array}$ & $4.75(2.5-43.5)$ & $13.5(2.3-38)$ & $5.78(3.3-19)$ & 0.356 \\
Sepsis, n (\%) & $8(80)$ & $8(80)$ & $8(80)$ & 0.99 \\
\hline Coma, n (\%) & $1(10)$ & $1(10)$ & $1(10)$ & $\mathrm{NA}$ \\
\hline Malabsorbtion, $\mathrm{n}(\%)$ & $1(10)$ & $1(10)$ & $1(10)$ & $\mathrm{NA}$ \\
\hline
\end{tabular}


Table 3. Clinic and hepatic measurements on the day 0 and 7

\begin{tabular}{|c|c|c|c|c|c|c|c|c|c|}
\hline & & roup 0 & & & Froup $\mathrm{S}$ & & & $\operatorname{roup} \mathbf{F}$ & \\
\hline & Day 0 & Day 7 & $\underset{\text { value }}{p}$ & Day 0 & Day 7 & $\begin{array}{c}p \\
\text { value }\end{array}$ & Day 0 & Day 7 & $\underset{\text { value }}{p}$ \\
\hline Weight (kg) & $\begin{array}{c}4.75 \\
(2.5-43.5)\end{array}$ & $\begin{array}{c}4.82 \\
(2.6-43.5)\end{array}$ & 0.026 & $\begin{array}{c}13.5 \\
(2.3-38)\end{array}$ & $\begin{array}{c}13.6 \\
(2.7-38)\end{array}$ & 0.018 & $\begin{array}{c}5.78 \\
(3.3-19)\end{array}$ & $\begin{array}{c}5.95 \\
(3.5-19)\end{array}$ & 0.012 \\
\hline MUAC (cm) & $\begin{array}{c}12.75 \\
(10.1-25)\end{array}$ & $\begin{array}{c}12.85 \\
(10.1-25)\end{array}$ & 0.083 & $\begin{array}{c}18.4 \\
(10.8-28)\end{array}$ & $\begin{array}{c}18.4 \\
(11-28)\end{array}$ & 0.059 & $\begin{array}{c}14.1 \\
(11.8-23.4)\end{array}$ & $\begin{array}{c}14.2 \\
(11.8-23.4)\end{array}$ & 0.052 \\
\hline Glucose (mg/dl) & $\begin{array}{c}85.5 \\
(64-110)\end{array}$ & $\begin{array}{c}84.5 \\
(61-108)\end{array}$ & 0.959 & $\begin{array}{c}95 \\
(64-122)\end{array}$ & $\begin{array}{c}88 \\
(66-105)\end{array}$ & 0.721 & $\begin{array}{c}87 \\
(60-110)\end{array}$ & $\begin{array}{c}93.5 \\
(72-120)\end{array}$ & 0.153 \\
\hline $\operatorname{AST}(\mathrm{UI} / \mathrm{L})$ & $\begin{array}{c}41 \\
(15-232)\end{array}$ & $\begin{array}{c}40 \\
(12-276)\end{array}$ & 0.386 & $\begin{array}{c}54 \\
(11-279)\end{array}$ & $\begin{array}{c}56 \\
(17-372)\end{array}$ & 0.26 & $\begin{array}{c}68 \\
(14-571)\end{array}$ & $\begin{array}{c}53.5 \\
(16-224)\end{array}$ & 0.646 \\
\hline ALT (UI/L) & $\begin{array}{c}23.5 \\
(10-141)\end{array}$ & $\begin{array}{c}20.5 \\
(9-354)\end{array}$ & 0.953 & $\begin{array}{c}31.5 \\
(10-255)\end{array}$ & $\begin{array}{c}29 \\
(10-124)\end{array}$ & 0.169 & $\begin{array}{c}19.5 \\
(10-378)\end{array}$ & $\begin{array}{c}23.5 \\
(9-241)\end{array}$ & 0.202 \\
\hline $\operatorname{ALP}(\mathbf{U I} / \mathbf{L})$ & $\begin{array}{c}135.5 \\
(57-954)\end{array}$ & $\begin{array}{c}142 \\
(83-1051)\end{array}$ & 0.005 & $\begin{array}{c}161.5 \\
(97-431)\end{array}$ & $\begin{array}{c}176.5 \\
(103-372)\end{array}$ & 0.799 & $\begin{array}{c}239 \\
(51-783)\end{array}$ & $\begin{array}{c}257 \\
(72-652)\end{array}$ & 0.475 \\
\hline GGT (UI/L) & $\begin{array}{c}55 \\
(24-200)\end{array}$ & $\begin{array}{c}58 \\
(24-170)\end{array}$ & 0.959 & $\begin{array}{c}51.5 \\
(15-545)\end{array}$ & $\begin{array}{c}93 \\
(12-345)\end{array}$ & 0.508 & $\begin{array}{c}54 \\
(14-240)\end{array}$ & $\begin{array}{c}39 \\
(14-238)\end{array}$ & 0.859 \\
\hline $\begin{array}{l}\text { T. bilirubin } \\
\text { (mg/dl) }\end{array}$ & $\begin{array}{c}0.5 \\
(0.2-16)\end{array}$ & $\begin{array}{c}0.6 \\
(0.2-18)\end{array}$ & 0.440 & $\begin{array}{c}0.5 \\
(0.2-25)\end{array}$ & $\begin{array}{c}0.3 \\
(0.2-20)\end{array}$ & 0.06 & $\begin{array}{c}0.3 \\
(0.2-18.6)\end{array}$ & $\begin{array}{c}0.4 \\
(0.2-18.8)\end{array}$ & 0.301 \\
\hline $\begin{array}{l}\text { U. bilirubin } \\
\text { (mg/dl) }\end{array}$ & $\begin{array}{c}0.3 \\
(0.1-7.6)\end{array}$ & $\begin{array}{c}0.35 \\
(0.1-7)\end{array}$ & 0.752 & $\begin{array}{c}0.25 \\
(0.1-10)\end{array}$ & $\begin{array}{c}0.15 \\
(0.1-10.8)\end{array}$ & 0.063 & $\begin{array}{c}0.2 \\
(0.1-11.8)\end{array}$ & $\begin{array}{c}0.2 \\
(0.1-11.6)\end{array}$ & 0.197 \\
\hline Bile acid (umol/L) & $\begin{array}{c}9.8 \\
(0.1-109)\end{array}$ & $\begin{array}{c}6.6 \\
(0.2-31)\end{array}$ & 0.575 & $\begin{array}{c}5.8 \\
(0.1-120)\end{array}$ & $\begin{array}{c}7.6 \\
(0.7-195)\end{array}$ & 0.878 & $\begin{array}{c}4.3 \\
(0.1-18.6)\end{array}$ & $\begin{array}{c}4.1 \\
(0.1-6)\end{array}$ & 0.878 \\
\hline PT & $\begin{array}{c}14.1 \\
(11.5-92.8)\end{array}$ & $\begin{array}{c}14.5 \\
(12-45.6)\end{array}$ & 0.813 & $\begin{array}{c}13.2 \\
(11-76)\end{array}$ & $\begin{array}{c}13.5 \\
(12-71)\end{array}$ & 0.610 & $\begin{array}{c}15 \\
(12-43)\end{array}$ & $\begin{array}{c}14.2 \\
(12-39)\end{array}$ & 0.074 \\
\hline APTT (s) & $\begin{array}{c}30.2 \\
(21-103)\end{array}$ & $\begin{array}{c}31 \\
(21-59)\end{array}$ & 0.359 & $\begin{array}{c}22.5 \\
(18-51)\end{array}$ & $\begin{array}{c}27 \\
(20-48)\end{array}$ & 0.018 & $\begin{array}{c}38 \\
(22-60)\end{array}$ & $\begin{array}{c}32 \\
(25-50)\end{array}$ & 0.114 \\
\hline INR & $\begin{array}{c}1.2 \\
(0.9-10.1)\end{array}$ & $\begin{array}{c}1.25 \\
(1-4.3)\end{array}$ & 0.602 & $\begin{array}{c}1.1 \\
(0.9-6.5)\end{array}$ & $\begin{array}{c}1.1 \\
(1-6.1)\end{array}$ & 0.957 & $\begin{array}{c}1.3 \\
(1.1-3.5)\end{array}$ & $\begin{array}{c}1.2 \\
(1-3.1)\end{array}$ & 0.071 \\
\hline $\begin{array}{l}\text { Total protein } \\
\text { (g/dl) }\end{array}$ & $\begin{array}{c}5.4 \\
(4.2-6.3)\end{array}$ & $\begin{array}{c}5.8 \\
(4.4-7.3)\end{array}$ & 0.066 & $\begin{array}{c}6.1 \\
(3.4-8.2)\end{array}$ & $\begin{array}{c}6.5 \\
(3.6-7.4)\end{array}$ & 0.359 & $\begin{array}{c}5.8 \\
(4-7.4)\end{array}$ & $\begin{array}{c}6.3 \\
(4.5-7.6)\end{array}$ & 0.413 \\
\hline Albumin (g/dl) & $\begin{array}{c}3.3 \\
(2.8-3.9)\end{array}$ & $\begin{array}{c}3.6 \\
(3-4.1)\end{array}$ & 0.073 & $\begin{array}{c}3.9 \\
(2.5-4.9)\end{array}$ & $\begin{array}{c}3.9 \\
(2.9-4.7)\end{array}$ & 0.765 & $\begin{array}{c}3.7 \\
(2.2-4.5)\end{array}$ & $\begin{array}{c}3.8 \\
(2.8-4.7)\end{array}$ & 0.258 \\
\hline Prealbumin (g/dl) & $\begin{array}{c}0.14 \\
(0.07-0.4)\end{array}$ & $\begin{array}{c}0.18 \\
(0.08-0.5)\end{array}$ & 0.005 & $\begin{array}{c}0.13 \\
(0.04-0.32)\end{array}$ & $\begin{array}{c}0.18 \\
(0.08-0.38)\end{array}$ & 0.008 & $\begin{array}{c}0.13 \\
(0.02-0.22)\end{array}$ & $\begin{array}{c}0.21 \\
(0.1-0.26)\end{array}$ & 0.005 \\
\hline $\begin{array}{l}\text { Cholesterol } \\
(\mathrm{mg} / \mathrm{dl})\end{array}$ & $\begin{array}{c}136 \\
(71-172)\end{array}$ & $\begin{array}{c}152 \\
(86-198)\end{array}$ & 0.025 & $\begin{array}{c}150 \\
(116-307)\end{array}$ & $\begin{array}{c}143 \\
(110-304)\end{array}$ & 0.386 & $\begin{array}{c}136 \\
(46-217)\end{array}$ & $\begin{array}{c}133 \\
(82-187)\end{array}$ & 0.445 \\
\hline $\begin{array}{l}\text { Triglyceride } \\
\text { (mg/dl) }\end{array}$ & $\begin{array}{c}124 \\
(52-346)\end{array}$ & $\begin{array}{c}153 \\
(103-305)\end{array}$ & 0.037 & $\begin{array}{c}116 \\
(29-143)\end{array}$ & $\begin{array}{c}154 \\
(98-209)\end{array}$ & 0.005 & $\begin{array}{c}118 \\
(47-205)\end{array}$ & $\begin{array}{c}125 \\
(73-355)\end{array}$ & 0.575 \\
\hline HDL (mg/dl) & $\begin{array}{c}30 \\
(2-57)\end{array}$ & $\begin{array}{c}36 \\
(8-42)\end{array}$ & 0.281 & $\begin{array}{c}29 \\
(10-49)\end{array}$ & $\begin{array}{c}35 \\
(10-41)\end{array}$ & 0.444 & $\begin{array}{c}28 \\
(10-48)\end{array}$ & $\begin{array}{c}31 \\
(15-43)\end{array}$ & 0.259 \\
\hline LDL (mg/dl) & $\begin{array}{c}74 \\
(12-113)\end{array}$ & $\begin{array}{c}82 \\
(18-156)\end{array}$ & 0.286 & $\begin{array}{c}85 \\
(73-231)\end{array}$ & $\begin{array}{c}81 \\
(44-239)\end{array}$ & 0.059 & $\begin{array}{c}83 \\
(26-133)\end{array}$ & $\begin{array}{c}78 \\
(25-136)\end{array}$ & 0.878 \\
\hline TAC (mmol/L) & $\begin{array}{c}1.15 \\
(0.92-1.67)\end{array}$ & $\begin{array}{c}1.12 \\
(0.87-1.63)\end{array}$ & 0.721 & $\begin{array}{c}1.08 \\
(0.86-1.55)\end{array}$ & $\begin{array}{c}1 \\
(0.52-2.4)\end{array}$ & 0.262 & $\begin{array}{c}1.1 \\
(0.74-1.29)\end{array}$ & $\begin{array}{c}1 \\
(0.92-1.52)\end{array}$ & 0.203 \\
\hline CRP (mg/dl) & $\begin{array}{c}3.7 \\
(0.6-12)\end{array}$ & $\begin{array}{c}1.5 \\
(0.2-6.2)\end{array}$ & 0.046 & $\begin{array}{c}7.2 \\
(0.9-14)\end{array}$ & $\begin{array}{c}4.6 \\
(0.37-6.6)\end{array}$ & 0.036 & $\begin{array}{c}3.77 \\
(0.5-12)\end{array}$ & $\begin{array}{c}2.8 \\
(0.2-5.6)\end{array}$ & 0.033 \\
\hline
\end{tabular}

Data are shown as median (minimum-maximum). MUAC = mid-upper-arm-circumference, AST $=$ aspartate transaminase, ALT $=$ alanine transaminase, ALP $=$ alkaline phosphatase, GGT $=$ gamma glutamyl transferase $(\mathrm{GGT})$, T. Bilirubin $=$ total bilirubin, $\mathrm{U}$. Bilirubin $=$ unconjugated bilirubin, $\mathrm{PT}=$ prothrombin time, APTT $=$ activated partial thromboplastin time, INR $=$ international normalized ratio, HDL $=$ high-density lipoprotein cholesterol, LDL $=$ low-density lipoprotein cholesterol, $\mathrm{TAC}=\mathrm{Total}$ antioxidant capacity, $\mathrm{CRP}=\mathrm{C}$-reactive protein 


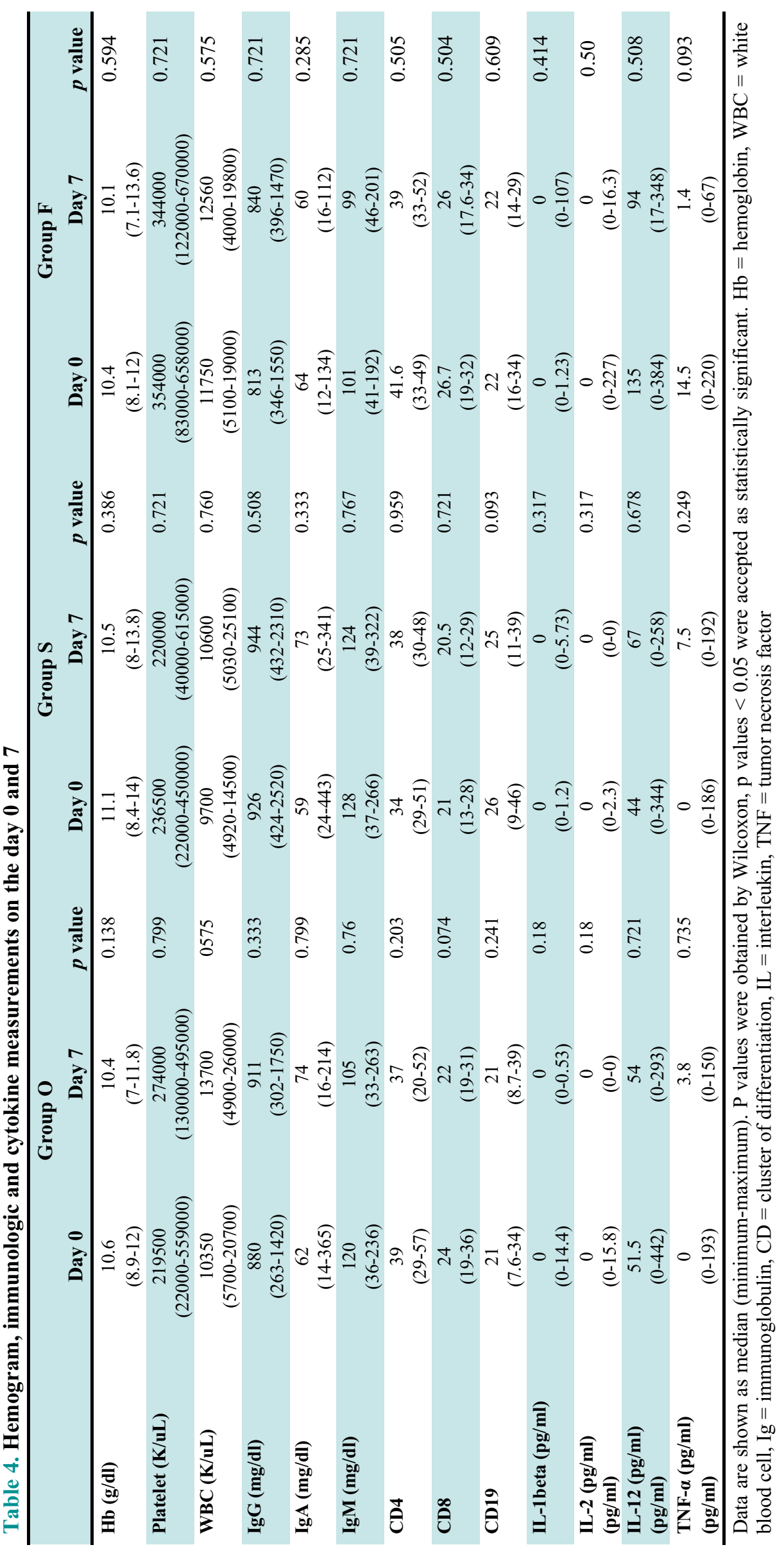


was reported to have no significant effect on upper arm circumference and body weight [6]. Three lipid emulsions were found effective in terms of weight gain and no significant difference was found between those emulsions in the present study.

Goulet et al. [7] reported that there was not any significant change in leukocyte, platelet and hemoglobin levels in some children who had long term soybean oil and olive oil based lipid emlusions. In this study, as the other studies, no effect of OO, SO and omega-3 fatty acid was observed on hemogram analysis.

Hyperglycemia or hipoglycemia was not detected in any of the patient. This may indicatethe protective effect of lipid emulsion for hyperglycemia [8]. Such effect was observed in all ILEs used in three groups in the present study. Furthermore, addition of lipid to PN protects from hyperinsulinism and hepatic steatosis due to excessive glucose intake [9]. There was no significant change in AST, ALT, GGT, direct bilirubin levels in any of the groups. The studies showed positive effect of FO procedure to reduce direct bilirubin level [1]. There are studies reporting PT and APTT prolongation by use of SO ILE [10]. In the present study, a significant increase of APTT levels within normal limits was observed in the group where SO based lipid emulsion was used at day 7 . The patients receiving SO based ILE should be closely monitored for APTT levels. An increase in ALP level within normal limits was observed in those receiving OO based lipid emulsion. For this increase, there was no difference between the other groups. Significant disruption was not detected in hepatic functions during short term use of SO based ILE, OO based ILE and omega-3 fatty acid solutions.

There is a study reporting that excess use of omega-6 PUFA caused a decrease in bile flow [11]. In the present study, an increase was detected in serum bile acids in the group using soybean based ILE with PUFA content whereas a decrease was observed in the group where OO based lipid emulsion was used. However, such changes were not statistically significant.

Despite the increase in hepatic cholesterol production under stress, plasma cholesterol concentration decreased with both HDL and LDL [12]. A significant increase in triglyceride levels within normal limits was detected in those who receive $\mathrm{OO}$ and SO in the present study. We also detected a significant increase in total cholesterol levelsin the group receiving OO. These increased cholesterol levels were in normal limits. The condition that TG level exceeds $400 \mathrm{mg} / \mathrm{dl} \mathrm{re}-$ quiring restriction of ILE administration was not detected in the patients of our study [13]. The HDL levels in our study increased in those receiving olive oil and omega-3 fatty acid and tended to decrease less in those receiving soybean oil. Goren et al. [14] reported a decrease in TG and total cholesterol levels by use of omega-3 fatty acid in the children and an increase in HDL cholesterol. Calkins et al. [15] detected an increase in TG level in the patients receiving SO and a significant decrease in TG level in those who receive FO in addition to their PN. Park et al. [16] reported an increase in lipoprotein lipase and a decrease in TG levels by use of omega-3 fatty acid. Similar to the aforesaid studies, we did not detect any significant increase in TG and total cholesterol levels in the group where omega-3 fat acid was added; HDL cholesterol level increase was not significant.

Leite et al. [17] and Delgado Artur Figueiredo et al. [18] reported an increase in prealbumin level by short term parenteral nutrition in the children with critical disease. Prealbumin levels significantly increased in all groups at day 7. Such increase in prealbumin level was not different between the groups.

In a previous study analysing antioxidant alpha tocopherol content in ILE detected the highest level by FO and then OO; the lowest level was detected in SO based lipid emulsions [19]. Pironi et al. [20] reported that lipid peroxidation increases in PN by use of ILE with high PUFA content. Goulet et al. [7] detected higher lipid peroxidation product in SO based lipid emulsions than OO based ILE in their study. Antebi et al. [21] reported that addition of omega-3 into the PN create higher antioxidant level when compared with use of soybean oil only. In the present study, antioxidant capacity levels were preserved in OO receivers, decreased in SO receivers and increased in the group where omega-3 was added. However, such changes were not significant. This may depend on natural antioxidant characteristics of $\mathrm{OO}$ and omega 3.

Dahlstrom et al. [10] reported no change in immunoglobulin levels in their study on the children who received SO based lipid emulsion. In our study, there was not any significant change in IgG, Ig A, Ig M levels in any of the groups before $\mathrm{PN}$ and no change was detected at day 7 . 
In previous study where $\mathrm{SO}$ rich in omega- 6 PUFA and effects of omega-3 were compared, n-3 PUFA products were reported to suppress production of proinflammatory cytokines and use of SO based ILE increase production of such cytokines [3]. OO based ILE is reported to be immunologically neutral [22]. Furthermore, TNF-alpha and IL-1 beta production are reported to decrease by both soybean oil and olive oil [23, 24]. Granato et al. [24]suggested that OO and $\mathrm{SO}$ based lipid emulsions cause a tendency of decrease in IL-1 beta and TNF-alpha levels. The previous studies reported that blood level of IL-12 is significantly lower by use of omega-3 fatty acid when compared with OO and n6-PUFA receivers [25]. We observed that blood levels of cytokines did not change by short term use of intravenous lipid emulsions.

It was reported that all PUFAs may suppress lymphocyte proliferation $[23,26,27]$. Among these, DHA and EPA were detected as a strong inhibitor of lymphocyte proliferation [26, 27]. It is also reported that lymphocyte proliferation suppressed with SO is not affected by $\mathrm{OO}$ based lipid emulsion [23, 24, 27]. It was reported in a study associated with use of fish oil that fish oil does not affect lymphocyte subgroup distribution and lymphocyte proliferation [28]. It is also reported that omega-3 PUFAs may reduce $\mathrm{T}$ cell ratio [29]. Such different results reported for omega-3 fatty acids may depend on the dosage. The patient groups of the present study did not present a significant change in lymphocyte subgroup distribution by PN. $\mathrm{OO}$ and SO based lipid emulsion and omega-3 fat acid solution did not affect lymphocyte subgroup distribution in short term use.

The balance between omega- 6 and omega- 3 fatty acids seem to be important for cytokine production. Sole use of ILE rich in omega-6 PUFA should be avoided to prevent immune suppression. Different possible effects of lipid emulsions on immunomodulatory and inflammatory cytokines may be used to treat the underlying disease. Until such effects are clearly understood, administration of $\mathrm{SO}, \mathrm{OO}$ and $\mathrm{FO}$ based lipid emulsions may be more physiological rather than providing ILE from a single source in PICU patients. There are no definite suggestions on the best form or start time of parenteral nutrition in critically ill children [30].

\section{Limitations}

The limitations of this study are that the number of patients is small and the follow-up period is short. The lack of this study is due to many factors that affect biochemical test results and cytokine levels in patients.

\section{CONCLUSION}

The use of OO, SO and FO based lipid emulsions in pediatric intensive care unit patients with short term parenteral nutrition is clinically and biochemically useful. FO and $\mathrm{OO}$ based lipid emulsions may provide more contribution to protection of antioxidant capacity in critically ill children. These three lipid emulsions have no effect on immune system in pediatric intensive care unit patients during short term use. OO, SO and FO based lipid emulsions may be used safely in critically ill patients. More randomized controlled studies with larger patient series are needed to prevent deficiency of essential fatty acid and to clarify immunological effects of ILEs as a main energy source.

\section{Conflict of interest}

The authors disclosed no conflict of interest during the preparation or publication of this manuscript.

\section{Financing}

The authors disclosed that they did not receive any grant during conduction or writing of this study.

\section{REFERENCES}

1. Hojsak I, Colomb V, Braegger C, Bronsky J, Campoy C, Domellöf $\mathrm{M}$, et al. ESPGHAN committee on nutrition position paper. Intravenous lipid emulsions and risk of hepatotoxicity in infants and children: a systematic review and meta-analysis. J Pediatr Gastroenterol Nutr 2016;62:776-92.

2. Waitzberg DL, Torrinhas RS, Jacintho TM. New parenteral lipid emulsions for clinical use. J Parenter Enter Nutr 2006;30:351-67.

3. Mayer K, Gokorsch S, Fegbeutel C, Hattar K, Rosseau S, Walmrath D, et al.Parenteral nutrition with fish oil modulates cytokine response in patients with sepsis. Am J Respir Crit Care Med 2003;167:1321-8.

4. Wanten GJA. Parenteral lipid tolerance and adverse effects: fat chance for trouble? JPEN J Parenter Enteral Nutr 2015;39:33-8. 5. Mehta NM, Compher C. A.S.P.E.N. Clinical Guidelines: nutrition support of the critically ill child. JPEN J Parenter Enteral Nutr 2009;33:260-76.

6. Beaufrere B. Eflicacite nutritionnelle et metabolique de Cli- 
nOleic 20\%. Nutr Clin Metabol 1996;10:29-31.

7. Goulet O, de Potter S, Antebi H, Driss F, Colomb V, Bereziat $\mathrm{G}$, et al. Long-term efficacy and safety of a new olive oil-based intravenous fat emulsion in pediatric patients: a double-blind randomized study. Am J Clin Nutr 1999;70:338-45.

8. Shulman RJ, Phillips S. Parenteral nutrition in infants and children. J Pediatr Gastroenterol Nutr 2003;36:587-607.

9. Oshita M, Takehara H, Yamaguchi M, Doi K, Ueda N, Naito $\mathrm{S}$, et al.Significance of administration of fat emulsion: hepatic changes in infant rats receiving total parenteral nutrition with and without fat. Clin Nutr 2004;23:1060-8.

10. Dahlström KA, Goulet OJ, Roberts RL, Ricour C, Ament ME. Lipid tolerance in children receiving long-term parenteral nutrition: a biochemical and immunologic study. J Pediatr 1988;113:985-90.

11. Ythier-Moury P, Dutot G, Melin C. Modifications of biliary secretion associated with parenteral nutrition in the rat: influence of fat emulsion composition. Clin Nutr 1990;9:26.

12. Calder PC. Lipids and the critically ill patient. Nestle Nutr Workshop Ser Clin Perform Programme 2003;8:75-91.

13. Calder PC, Jensen GL, Koletzko BV, Singer P, Wanten GJA.

Lipid emulsions in parenteral nutrition of intensive care patients: current thinking and future directions. Intens Care Med 2010;36:735-49.

14. Goren A, Stankiewicz H, Goldstein R, Drukker A. Fish oil treatment of hyperlipidemia in children and adolescents receiving renal replacement therapy. Pediatrics 1991;88:265-8.

15. Calkins KL, Dunn JCY, Shew SB, Reyen L, Farmer DG, Devaskar SU, et al. Pediatric intestinal failure-associated liver disease is reversed with 6 months of intravenous fish oil. JPEN J Parenter Enteral Nutr 2014;38:682-92.

16. Park Y, Harris WS. Omega-3 fatty acid supplementation accelerates chylomicron triglyceride clearance. J Lipid Res 2003;44:455-63.

17. Leite HP, de Carvalho WB, Fisberg M. Nutritional and metabolic assessment of critically ill children. Sao Paulo Med J 1996;114:1156-61.

18. Delgado AF, Kimura HM, Cardoso AL, Uehara D, Carrazza FR. Nutritional follow-up of critically ill infants receiving short term parenteral nutrition. Rev Hosp Clin Fac Med Sao Paulo 2000;55:3-8.

19. Xu Z, Harvey KA, Pavlina TM, Zaloga GP, Siddiqui RA. To- copherol and tocotrienol homologs in parenteral lipid emulsions. Eur J Lipid Sci Technol 2015;117:15-22.

20. Pironi L, Guidetti M, Zolezzi C, Fasano MC, Paganelli F, Merli C, et al. Peroxidation potential of lipid emulsions after compounding in all-in-one solutions. Nutrition 2003;19:784-8.

21. Pironi L, Guidetti M, Zolezzi C, Fasano MC, Paganelli F, Merli C, et al. Liver function and plasma antioxidant status in intensive care unit patients requiring total parenteral nutrition: comparison of 2 fat emulsions. JPEN J Parenter Enteral Nutr 2004;28:142-8.

22. Wanten GJ, Calder PC. Immune modulation by parenteral lipid emulsions. Am J Clin Nutr 2007;85:1171-84.

23. Moussa M, Le Boucher J, Garcia J, Tkaczuk J, Ragab J, Dutot $\mathrm{G}$, et al. In vivo effects of olive oil-based lipid emulsion on lymphocyte activation in rats. Clin Nutr 2000;19:49-54.

24. Granato D, Blum S, Rössle C, Le Boucher J, Malnoë A, Dutot G. Effects of parenteral lipid emulsions with different fatty acid composition on immune cell functions in vitro. JPEN J Parenter Enteral Nutr 2000;24:113-8.

25. Puertollano MA, Puertollano E, Ruiz-Bravo A, JiménezValera M, De Pablo MA, De Cienfuegos GA. Changes in the immune functions and susceptibility to Listeria monocytogenes infection in mice fed dietary lipids. Immunol Cell Biol 2004;82:370-6.

26. Kumar GS, Das UN, Kumar KV, Madhavi N, Das NP, Tan BKH. Effect of n-6 and n-3 fatty acids on the proliferation of human lymphocytes and their secretion of TNF- $\alpha$ and IL-2 in vitro. Nutr Res 1992;12:815-23.

27. Calder PC, Newsholme EA. Polyunsaturated fatty acids suppress human peripheral blood lymphocyte proliferation and interleukin-2 production. Clin Sci 1992;82:695-700.

28. Schauder P, Röhn U, Schäfer G, Korff G, Schenk HD. Impact of fish oil enriched total parenteral nutrition on DNA synthesis, cytokine release and receptor expression by lymphocytes in the postoperative period. Br J Nutr 2002;87:103-10.

29. Wu D, Meydani SN, Meydani M, Hayek MG, Huth P, Nicolosi RJ. Immunologic effects of marine- and plant-derived n-3 polyunsaturated fatty acids in nonhuman primates. Am J Clin Nutr 1996;63:273-80.

30. Lapillonne A, Mis NF, Goulet O, van den Akker CH, Wu J, Koletzko B. ESPGHAN/ESPEN/ESPR/CSPEN guidelines on pediatric parenteral nutrition: Lipids. Clin Nutr 2018;37:2324-36. 